\title{
IMPACT OF COVID-19 AS A PANDEMIC ON VARIOUS INDUSTRIES: A
} CONCEPTUAL PAPER

\author{
Dr.Sadia Shaikh \\ Assistant Professor, Benazir School of Business, \\ Benazir Bhutto Shaheed University, Karachi, Pakistan \\ Email:dr.sadiashaikh@bbsul.edu.pk \\ Muhammad Faisal Sultan \\ Assistant Professor, Department of Business Administration, \\ KASBIT, Karachi, Pakistan \\ Email:mfaisal@kasbit.edu.pk

\section{Dr.Tasleem Arif} \\ Assistant Professor, Department of Sports Sciences \& Physical Education, \\ Sarhad University of Science and Information Technology, Peshawar, Pakistan \\ Email:tasleem.ss@suit.edu.pk
}

\begin{abstract}
Pandemics always create dreadful effects not only on human life but also drastically influence businesses and industries. Historical evidence has apparently indicated that the outbreak of Spanish flu, SARS, MERS, and Ebola viruses, all created radical impacts on businesses around the globe, leaving behind the economic structures into miseries and deprivations. Similar is the case of COVID-19 outbreak which instigated from China and dispersed all over the globe. In Pakistan, the first case was reported in March 2020 and since then the government has relentlessly tried to impose lockdown and social distancing in order to avert the harm. It has been substantiated that the public isolations and lockdowns have not only yielded negative impacts on the economy but also on different forms of business and employment. Therefore, this study is aimed to analyze potential impacts of COVID-19 on different forms of industries in Pakistan through gathering the public opinion as the source of data. The study is one of the preliminary studies therefore it is based on descriptive design in order to show perceived impact of outbreak of virus. Results indicated that the pandemic is harmful and affecting most of the business in negative manner however there are some businesses which are burgeoning on opportunities emerged from the pandemic and attaining growth due to the spread of the virus.
\end{abstract}

Keywords: COVID-19, Industries, Emerging Business Opportunities, Public Opinion, Descriptive Analysis. 


\section{INTRODUCTION}

Widespread diseases which are hard to restrict due to their pervasive transferability have drastically affected the human populations across the globe (Dimitri, 2015). However, the wealthier countries which possess better infrastructure, education and healthcare systems, ubiquitous technologies and mechanisms contend the effects of these pandemics by comprehensively implementing public health campaigns. Although COVID-19 is found to be more contiguous than HIV and influenza as it has severely affected even those economies which are considered to be developed and resilient to prevalent pandemics. The spread looks obvious as the previous pandemics like HIV, H1N1, H5N1 \& SARS all transmitted across borders to diminish the stability (Verikios, Sullivan, Stojanovski, Giesecke, \& Woo, 2016), as pandemics have the ability to threaten the political structures, social livings and economics (Davies, 2013) and bring widespread upheavals.

Smith, Machalaba, Seifman, Feferholtz and Karesh (2019), specified the analysis of the World Bank that the world economy has borne a loss of at least US $\$ 80$ billion due to epidemic and pandemic zoo noses from 1997 to 2009. Study further indicated that if healthcare systems part prevent these outbreaks then they might save US \$ 6.7 billion/ year, thus it is optimal to believe that the impact of these type of pandemic and zoo noses are not only limited to health sector but their spread is wider and catastrophic.

Contrary to that Bloom and Canning (2006) indicated that epidemics might not produce negative consequences on per capita income. Study indicated that this would happen as workers who die are replaced by others. In fact, this might increase GDP per capita at initial phases although this will not remain in positive condition in the long run. Therefore, according to Bloom and Canning (2006) it is still a debatable topic that whether GDP per capita will be affected positively or negatively. Although recent study claims that economic risks of epidemics are not trivial, and these are even of higher magnitude as compared to the risks to the health sector. This might be clarified from the Liberia where GDP growth was decreased by $8 \%$ due to the outbreak of Ebola virus from 2013 to 2014. On the other side outbreak of Ebola virus in West Africa resulted in decrease of death rates in the territory (Bloom, Cadarette \& Sevilla, 2018). Although studies regarding macroeconomics impacts of severe respiratory syndrome (SARS) epidemic in 2003 indicate the enormous negative 
consequences on form of subsequent decrease in consumption of different goods and increase of operating costs of businesses (McKibbin \& Fernando, 2020).

Moreover, disease also resulted in increase of risk premium for associated business in the location although determination of exact impact on any geographical location is bit subjective and varies from location to location. This variation is based on $(\boldsymbol{a})$ duration by which disease prevails in the location (b) group of people which is at risks? (c) Transmission of disease i.e. air-borne or blood-borne (Bloom \& Canning, 2006). Economic shocks due to epidemics will be transferred to other economies on the bases of their rate of exposure and vulnerabilities to the disease. Therefore COVID-19 as a global pandemic is a point which needs clarity and discussion although the virus is treated as more contagious than HIV which affects healthcare as well as psychology similarly as the threat of terrorism. Therefore, mass proportion will consider them at risk even the probability of death due to virus is low (McKibbin \& Fernando, 2020). On the other hand it has also been predicted that consequences of epidemic are not similar for all the sectors and there is even a probability of profit for some of the sectors like pharmaceutical or any other which might aid in control and safety (Bloom et.al., 2018).

Similarly, the insurance sector might face lots of trouble and have to bear high cost at least in short term similar is valid for livestock industry if the pandemic is also transmittable to animals. On the other hand impact of pandemic are also different to different social class as lower income group will face lack of access to healthcare facilities \& savings which are required to survive in the era of financial downturn (Bloom et al., 2018). Study of Bloom and Canning (2006) also highlighted the difference of impact which virus produces on business performance at different locations or continents. Study quoted survey of 8719 firms by World Economic Forum in 2004 that only $16 \%$ agrees to serious negative impact of virus on their business although the tool rose to $35 \%$ in low-income countries and to $45 \%$ in Sub Saharan African countries. Therefore, keeping all these possibilities and difference i.e. business categories and income groups (Bloom et.al., 2018), types of workers at risk and difference in business operations at different locations (Bloom \& Canning, 2006), 
there is a definite requirement of study on impacts of COVID-19 for different forms of business.

The study will be especially beneficial if it is derived not only from low income country likes Pakistan (Faisal, 2020; Salik, Ishfaq, Saeed, Noel\& Syed, 2015) \& there is no collaboration between national and provincial governments to stop and restrict COVID-19 (Faisal, 2020; Suleri, 2020). Moreover, Pakistan is not a social welfare state and cannot confine its citizens to their homes neither can provide free food and utilities at their doorstep (Suleri, 2020). Hence best way to formulate this study is to conduct it through public opinion regarding impact of COVID-19 on different business sectors in Pakistan, It has also been indicated by Deling Diren and Tiantian (2016) that public opinion is an effective tool to take contribution from Public in important matters. Hence conduction of the study looks optimal to provide clear picture of the perceived impact of COVID-19 on different business sectors of Pakistan.

\section{SIGNIFICANCE AND SCOPE}

Significance of this study has many folds as initially this is important for policy making in the critical scenario impaired by outbreak of COVID-19 under which there is lack of coordination between national government and provincial governments. Hence through public opinion the impact of COVID-19 on different forms of industries might assist governments in managing effective policies for different business sectors. Moreover, through this study managers and entrepreneurs might understand the risks which COVID-19 imposed to different forms of business. At last, the study might provide base to managers and corporate entrepreneurs to revamp strategies especially for those industries which will be tremendously affected by COVID19.

\section{RESEARCH QUESTIONS}

- Does COVID-19 affect the economy of Pakistan negatively?

- Does COVID-19 produce similar impact on different business sectors in Pakistan?

- Is there a chance that any business sector might be affected positively by COVID-19? 
RESEARCH HYPOTHESES

H1O: COVID-19 does not produce significantly worse impact on business sectors

H1A: COVID-19 does not produce significantly worse impact on business sectors

\section{LITERATURE REVIEW}

Latest study indicated that pandemics are negatively associated with the economic activity as they cause decline in supply as well as demand (Eichenbaum, Rebelo \& Trabandt, 2020). Study of Correia and Luck (2020) also indicated the same that areas which are heavily affected by pandemics face relatively more decline in manufacturing, employments, manufacturing outputs, banks assets \& consumption, especially of durable goods.

Similarly, the analysis of 1918 influenza provided by Correia and Luck (2020) indicated that areas of USA which are more affected by influenza during 1918 to 1920 faced severe downturn in real economic activity. Although the pandemic was majorly outbreak in eastern part of the country and areas which are mainly affected by the pandemics were also exposed to several other economic shocks.

Bloom and Canning (2006) indicated that there are some epidemics which produces significant negative impacts on economic conditions although there is no clear evidence of negative consequences on GDP per capita. Therefore, it is better to restrict effects of epidemics to household levels, especially on poor class. Similarly, one of the early studies in India by Bloom and Mahal (1995) provides insignificant impact of AIDS epidemic on the per-capita income in India, regardless of its drastic impact on death rate and rate of welfare \& economy.

These drastic conditions are more explicitly explained by Bloom and Canning (2006) that families have to withdraw their savings and sell their assets for managing healthcare issues. In fact, relatives of these sick people also suffered as they have to take time off from their profession to take care of their relatives. Similar conditions were found due to the outbreaks of epidemics in Asian countries like China and Malaysia, where Nipah and Severe Acute Respiratory Syndrome (SARS) caused significant disruption to the economies. Nipah in Malaysia in 1998 caused evacuation of 618 homes \& 111 banks, shops, and schools with around 36,000 people lost their jobs and costing Malaysian economy around US \$ 582 million. Similarly Hong 
Kong suffers from $2.6 \%$ decrease in GDP, although the pandemic is not limited to these few countries it affect business of international businesses e.g. FedEx and well known airport shop Estée Lauder and thus shocks was transferred to entire globe. Moving towards another Asian country China where SARS in 2003, killed around 800 people and cost global economy around US \$ 40 billion.

Economic downturn found all over the globe as China suffered around $0.8 \%$ (Smith et.al., 2019). Although McCarthy (2020) indicated the impact of SARS all over the globe and indicated that Hong Kong $-2.63 \%$, China $-1.05 \%$, Singapore $-0.47 \%$, Malaysia $0.15 \%$, Philippines \& South Korea $-0.10 \%$ respectively and USA $0.07 \%$. Although the sectors which are mainly disrupted by SARS in 2003 are tourism, travel, retail, hotel and restaurant and the major fear behind these disruptions was transmission of virus from one person to another (Smith et.al. 2019).

Linking the literature with recent pasts i.e. outbreak of Ebola virus in Africa and South Korean Middle East Respiratory Syndrome (MERS) also produces negative impact on households, businesses, and economies. In 2013 to 2014 Ebola epidemic broke out in Africa and caused Liberia resulted in shift of GDP from $8.7 \%$ to $0.7 \%$. Similar sort of resulted obtained from other West-African country (Sierra Leone), whose GDP decreased significantly due to Ebola virus. Similarly outbreak of SARS in Korea produced significant fear in residents as well as government which resulted in closure of several business and get-togethers etc.(Smith et.al., 2019).

Last but not the least it has also been predicted that economic conditions all over Asia will be getting till 2021 due to the outbreak of novel COVID-19. Study further revealed that there will be a decline of $3.3 \%$ in economic growth of the region which will become stable in 2021 and reaches $6.1 \%$ if the effects of pandemic became over. Similarly study also indicated that developing Asia (excluding Hong Kong, China; the Republic of Korea; Singapore; and Taipei, China) will make economic growth by $2.4 \%$ which was previously around $5.7 \%$ in 2019. Country wise prediction indicated that China's economic growth for the current year will be pushed down to $2.3 \%$ although if economy able to recover from the shocks then it will reach $7.3 \%$ in 2021. Similarly, economic growth for India will be around $4.0 \%$ for this year although if the country able to remove the negatives 
of COVID-19 it will reaches $6.2 \%$. Furthermore, the overall cost of the pandemic is estimated up to US \$ 2.0 trillion to US \$ 4.1 trillion which is almost equivalent to $2.3 \%$ to $4.8 \%$ of world's gross domestic GDP (Asian Development Bank, 2020).

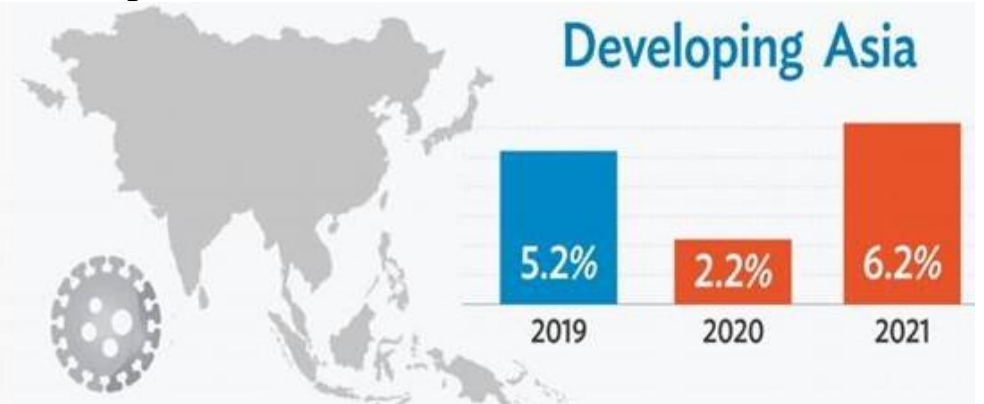

Figure-1: GDP Growth Forecast(Asian Development Bank, 2020)

The initial effect of COVID-19 on economy resembles the shocks produced by Global Great Recession of 2008-2009. The virus does not only affect economies but due to its breakout roads in all the cities are closed for each other. Moreover, other countries are also restricting individuals from entering their premises, especially from those locations which are infected by COVID-19 (McKibbin \& Fernando, 2020). Highlighting the impact of COVID-19 on the economy of Pakistan a report of Bijian (2020) indicated that the impact on country's economy is relaying on the time which has been lost in overcoming intensity of virus and its spread. Reports also quotes the analyses made by Asian Development Bank (2020) that COVID-19 will affect Pakistan economy in between US \$16.387 billion to US $\$ 4.95$ billion and might resulted in decrease of GDP by $1.57 \%$ and ultimately resulted in loss of 946,000 Jobs.

\section{RESPIRATORY PANDEMICS ON DIFFERENT FORMS OF BUSIENESS}

Impact of SARS: Outbreak of SARS in Hong Kong not only diminishes the level of GDP but also harms several business sectors including hotel, airline, and retail sector (Siu \& Wong, 2004). Although sector which experienced extreme negatives effects is tourism \& observes $68 \%$ decline in Hong Kong and $70 \%$ or higher in Singapore which also forced Singapore to shift 6600 staff of airline industry to unpaid leaves. Similarly, MERS also caused loss of US \$6 
billion to Asia-Pacific and US \$1 billion to North American airlines and carriers (Smith et.al., 2019).

The other sectors which received tremendous shocks from SARS are restaurants and retail as the decline in sales was around $10 \%$ to $50 \%$ in Hong Kong. The disease also cuts down road transport and traffic by $10-20 \%$ and the business of air industry was also been trashed significantly. In fact some of the analysts predict that disease may continue its second cycle in 2004 in Hong Kong while the outbreak of the same in China disrupted the global supply chain which was not in the case of Hong Kong where cross broader manufacturing had not been disturbed by SARS (Siu \& Wong, 2004).

Impact of MERS: Due to the outbreak of South Korean MERS in 2015 the food sector suffers 10\% decrease in production level as compared to the previous year. Similarly, entertainment and recreational sector suffered around $8.6 \%$ and publication, communication and information sector observed decline of $6.3 \%$ in level of production. On the other hand, $2.4 \%$ and $1.6 \%$ decline found in the transportation and storage and wholesale and retail sector, respectively. Tourism industry also suffered a lot and reported decrease of $41 \%$ less tourist in South Korea in mid-summer season which reaches to deficiency of $60 \%$ in the next month. At last electricity and electronics industry in Korea was also influenced by the outbreak of MERS and recorded $0.9 \%$ decline in productivity. Restrictions imposed on travelling also transfer the negative shocks to other economies as outbreak of MERS diminishes the Saudi-Arabian tourism industry by US $\$ 5$ billion/ year (Smith et.al., 2019).

Impacts of COVID-19: COVID-19 which belongs to the category of SARS and MERS is recently spreading all over the globe and as per March 1, 2020 it has affected 87, 137 people all over the globe. Although its transmission from one person to another is found to be less virulent than the other two zoo noses (Gao, Cao, Hong, Tang, Chen, Jin \& Yan, 2020). Hence point regarding treating outbreak as global pandemic or not? Is still under debate, on the other hand the outbreak of virus is creating anomaly in markets through fostering panic business and consumer sectors. Thus, the disease is also creating harmful impacts on stocks and government bills as initial results also suggested substantial decline in both of these parameters of financial investments (McKibbin \& Fernando, 2020). 


\section{RESEARCH METHODOLOGY}

Research Design: The experience from previous epidemics and pandemics like SARS and MERS and others provide us the way to develop implications of COVID-19. Although the declaration of COVID-19 as pandemic for entire world is still under the process of debate (McKibbin \& Fernando, 2020), hence it is inappropriate to implement concepts and implications of prior studies. Thus, the paper is based on Ontology as the research philosophy as the study will predict the extent to which COVID-19 might affect different forms of business. Thus, the main purpose of the paper is to validate the McKibbin and Fernando (2020) that COVID-19 is more contagious than influenza. The disease belongs to the family of SARS and MERS and thus it might be more contagious than all the other three disease. Hence linking the research with Ontology and critical realism is appropriate, as ontology is specification of conceptualization (Tashakkori \& Teddlie, 2008) a termed as science of existence (Sale, Lohfeld \& Brazil, 2002).

On the other side critical realism is to link ontology with quantitate designs and used to conceptualize those patterns which are real but neither imperfectly nor probabilistically apprehend able (Mc Manus, Mulhall, Ragab \& Arisha, 2017). The method (approach) is deductive, and it isa field experiment to collet public opinion with closed ended questionnaire (Sekaran \& Bougie, 2016) and crosssectional time horizon. (Saunders et.al., 2015 \& Sekaran \& Bougie, 2016)

Sampling Design: The sampling has been done in order to assure the contribution for all the provinces of Pakistan with maximum representation of educated respondents from youth. The study has been done through public opinion as the public opinion is an effective tool for policy making i.e. through analysis of opinion effective policies might be developed. This becomes more potent under those scenarios which are more important to local public (Burstein, 2003) which is similar to the recent conditions prevailing due to COVID-19. Therefore, in order to provide policy makers an insight the study combines the opinion of youth from Sindh.

Sindh has been selected to link the study as the province reported second most number of cases after Punjab moreover there is also a conflict in actual and officially reported number of cases of covid-19 (Tunio, 2020). The sample size for this study includes respondents 
from ten (10) top districts of Sindh (from Karachi to Larkana) on the bases of z-sum and composite index (Ahmed \& Mahmood, 2012).

The data basically collected from youth studying in universities and (HEIs) higher educational intuitions to comply with Kirby and Bryson (2002) and assure participation of youth in public opinion. It has also been ensured that there would be at least 100 respondents from each district as Sindh has massive variation in population of its district and number of higher educational institutes also varies significantly. Therefore, the major respondents are from Karachi, Hyderabad \& Sukkur, although other districts also have significant representation in the data the total sample size for the research is of 2000 respondents.

This has been done to assure the estimation given by Israel (1992) that for the population more than 100,000 the minimum sample size with error of $3 \%$ must be 1,111 . Although overall population of Sindh is 30.44 million and to avoid sampling error and biasness the sample size needs to be adequate (Taherdoost, 2017), therefore study utilizes the prediction of sample size made by Gill et al., (2010) that for population of 10 lac or above the minimum sample size for $97 \%$ is 1831. Therefore the study has been done on the data of 2000 respondents The sampling type incorporated in the study is nonprobability sampling as incorporated by Deling and Diren (2015), Sultan Ahmed Zafar (2017) and Sultan Omar and Imtiaz (2019) to collect data. The method was snow-ball sampling as used by the study of Wang, Pan, Wan, Tan, Xu, Ho and Ho (2020) on psychological impact of COVID-19. Thus, it is legitimate to declare the sampling is fruitful in identifying the impacts of COVID-19 \& also to increase reach of the document. Moreover, through this researcher also followed Adu-Gyamfi (2014) and trace youth of higher educational institutes through emails and networking to yield effective and authentic results.

Questionnaire: In order to collect data a self-administrated questionnaire has been developed which has two sections, the section $\mathrm{A}$ is to determine the ranking of industries on the bases of impact created by COVID-19. The section B is used to identify the impacts of COVID-19 on different industries. Each industry has four questions which are actually formulated on the bases of literature regarding decrease of operation, downsizing and measures and requirement of 
aid for each industry. These measures are transformed into Likert scale questions as the scale is common for collection of responses and most of the people are familiar to these types of questions and surveys. Moreover, the purpose of Likert scale is to gauge attitude which might varies on the bases of severity from person to person (Johns, 2005 \& Johns, 2010). Questionnaire is also transformed into Google doc in order to have response in quick time and also to diminish cost of data collection as done by Wang et.al., (2020) and distributed through email as well as WhatsApp and other social networking sites (AduGyamfi, 2014). Initially 3500 questionnaires were circulated although due to lack of interest, quarantine, and other issues the study has been conducted on 2000 responses.

\section{SATISTICAL TESTING AND ANALYSIS}

Dulock (1993) indicated that descriptive research designs are the most effective form of research designs when there is lack of knowledge about the phenomenon\& cross-sectional design are also the form of descriptive studies (Koh \& Owen, 2000). Thus, it is effective to conduct descriptive study on the perceived effect of COVID-19 on different industries operating in Pakistan. Initially the effects were determined for the impact of COVID-19 on economy of Pakistan and on different forms of industries through posing nominal questions indicate and then the detailed impact was analyzed through posing Likert scale questions.

\begin{tabular}{|c|c|c|c|c|c|}
\hline & & Frequency & Percent & $\begin{array}{c}\text { Valid } \\
\text { Percent }\end{array}$ & $\begin{array}{c}\text { Cumulative } \\
\text { Percent }\end{array}$ \\
\hline \multirow[t]{3}{*}{ Valid } & Yes & 1595 & 79.8 & 79.8 & 79.8 \\
\hline & No & 405 & 20.2 & 20.2 & 100.0 \\
\hline & Total & 2000 & 100.0 & 100.0 & \\
\hline
\end{tabular}

TABLE-1

PERCEIVED NEGATIVE IMPACT OF COVID-19

ON ECONOMY OF PAKISTAN 


\section{Negative Effecrt of COVID-19 on Economy of Pakistan}

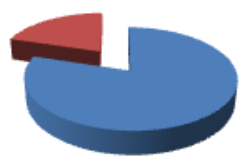

\begin{tabular}{|l|l|r|r|r|r|}
\hline & \multicolumn{2}{|c|}{ Frequency } & Percent & $\begin{array}{c}\text { Valid } \\
\text { Percent }\end{array}$ & $\begin{array}{c}\text { Cumulative } \\
\text { Percent }\end{array}$ \\
\hline Valid & Yes & 1700 & 85.0 & 85.0 & 85.0 \\
& No & 300 & 15.0 & 15.0 & 100.0 \\
& Total & 2000 & 100.0 & 100.0 & \\
& & & & \\
\hline
\end{tabular}

TABLE-2

PERCEIVED NEGATIVE IMPACT OF COVID-19

ON PER CAPITA INCOME IN PAKISTAN

\section{Negative Effect of COVID-19 on \\ Per Capita Income}

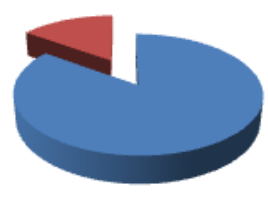

\begin{tabular}{|c|c|c|c|c|c|}
\hline & & Frequency & Percent & $\begin{array}{c}\text { Valid } \\
\text { Percent }\end{array}$ & $\begin{array}{c}\text { Cumulative } \\
\text { Percent }\end{array}$ \\
\hline \multirow[t]{3}{*}{ Valid } & Yes & 1610 & 80.5 & 80.5 & 80.5 \\
\hline & No & 390 & 19.5 & 19.5 & 100.0 \\
\hline & Total & 2000 & 100.0 & 100.0 & \\
\hline
\end{tabular}

TABLE-3

PERCEIVED IMPACT OF COVID-19 ON DIFFERENT INDUSTRIES OPERATING IN PAKISTAN 


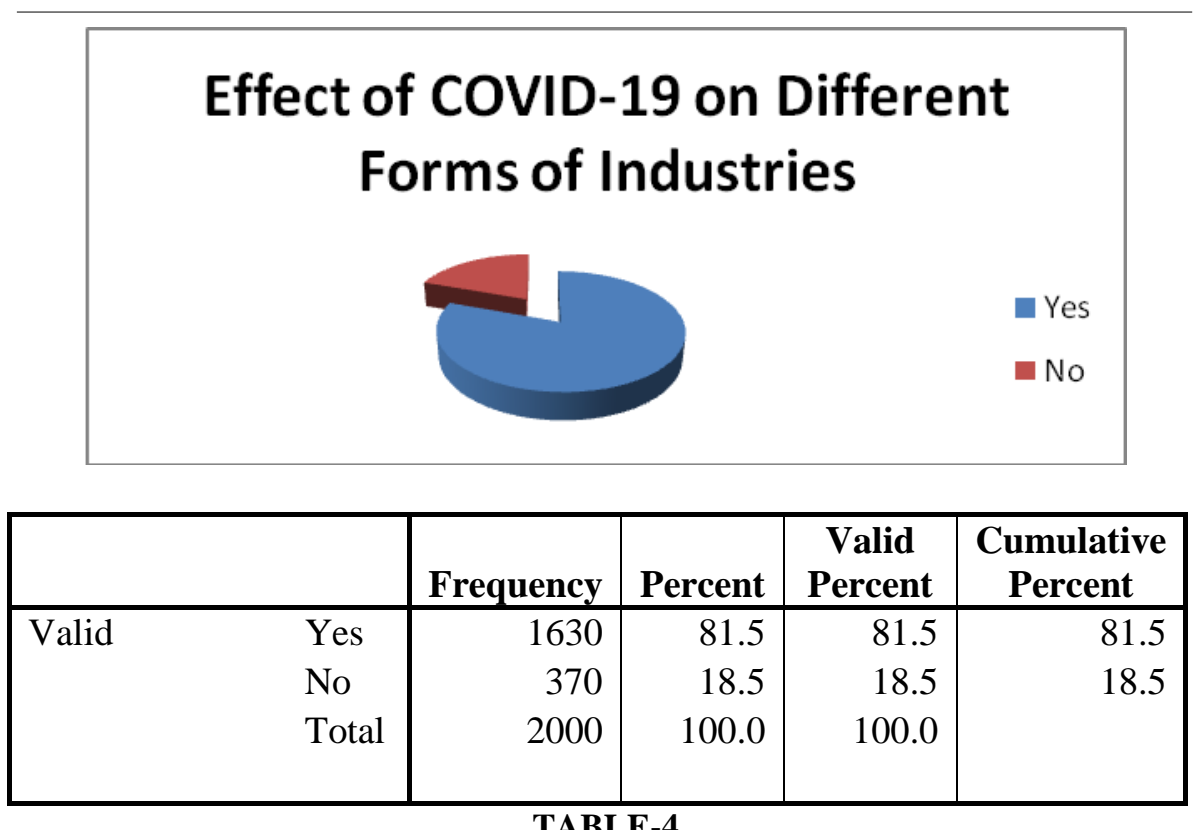

TABLE-4

PERCEIVED POSITIVE IMPACT OF COVID-19 ON INDUSTRIES

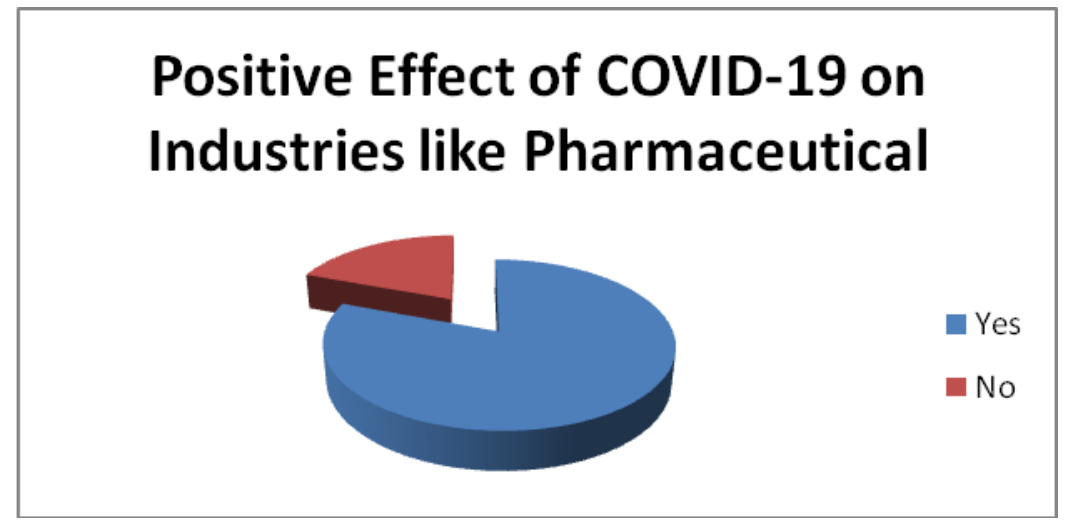

Tables 1 to Table 4 are indicating perceived impact of COVID19 on economy, per capita income and different industries operating in Pakistan. The results are gathered through posing nominal questions. Results indicated that it has been perceived by the youth that COVID19 produces drastic effects on economy of Pakistan and per capita income. Although it does not produce similar effects on all forms of industries and might foster sales and revenues of some industries' like pharmaceutical companies. 


\begin{tabular}{|l|r|r|}
\hline & \multicolumn{1}{|c|}{ N } & Mean \\
\hline Airline Industry & 2000 & 2.12 \\
Tourism Industry & 2000 & 2.09 \\
Textile Industry & 2000 & 2.38 \\
Higher Education Industry & 2000 & 10.65 \\
Online Industry & 2000 & 13.75 \\
Transportation Industry & 2000 & 3.75 \\
Wholesale and Retail Industry & 2000 & 9.75 \\
Fashion Industry & 2000 & 3.50 \\
Food and Beverage Industry & 2000 & 9.70 \\
Construction Industry & 2000 & 5.85 \\
School and High Schooling Industry & 2000 & 7.30 \\
Telecom Industry & 2000 & 9.55 \\
Publication and Print Industry & 2000 & 5.65 \\
Pharmaceutical Industry & 2000 & 12.95 \\
Automobile and Mechanical Industry & 2000 & 5.10 \\
News and Information Industry & 2000 & 11.25 \\
Banking Industry & 2000 & 7.35 \\
Information Technology Industry & 2000 & 9.50 \\
Hotel and Restaurant Industry & 2000 & 6.60 \\
Agriculture Industry (Livestock Sector) Industry & 2000 & 8.65 \\
Electrical and Electronics Industry & 2000 & 8.70 \\
Entertainment (Drama and Film Production) & 2000 & 4.85 \\
Distribution and Logistic Industry & 2000 & 12.20 \\
Agriculture Industry (Crop Sector) Industry & 2000 & 3.05 \\
Valid N (list-wise) & 2000 & \\
\hline
\end{tabular}

TABLE-5

PERCEIVED HARM CAUSED BY COVID-19 TO DIFFERENT INDUSTRIES

Table 5 indicating perceived harmful consequences for different form of industries on the bases of mean score (average). Table indicating that COVID-19 will produce most drastic impact on tourism industry and the industry which will be least affect in comparison to the others is online industry. 


\begin{tabular}{|c|c|c|}
\hline \multicolumn{3}{|l|}{ Descriptive Statistics } \\
\hline & $\mathbf{N}$ & Mean \\
\hline $\begin{array}{l}\text { Companies will minimize its operations - Airline } \\
\text { Industry }\end{array}$ & 2000 & 3.96 \\
\hline There will be a down-sizing in industry - Airline Industry & 2000 & 3.97 \\
\hline $\begin{array}{l}\text { Industry will require foreign aid for getting stable - } \\
\text { Airline Industry }\end{array}$ & 2000 & 4.00 \\
\hline $\begin{array}{l}\text { Industry will require support from national } \\
\text { government for getting stable - Airline Industry } \\
\text { Valid N (list-wise) }\end{array}$ & 2000 & 3.27 \\
\hline \multicolumn{3}{|l|}{$\begin{array}{c}\text { TABLE-6 } \\
\text { PERCEIVED NEGATIVE EFFECT OF COVID-19 } \\
\text { ON AIRLINE INDUSTRY IN PAKISTAN } \\
\end{array}$} \\
\hline & $\mathbf{N}$ & Mean \\
\hline $\begin{array}{l}\text { There will be a down-sizing in industry - Tourism } \\
\text { Industry }\end{array}$ & 2000 & 3.95 \\
\hline $\begin{array}{l}\text { Companies will minimize its operations - Tourism } \\
\text { Industry }\end{array}$ & 2000 & 3.98 \\
\hline $\begin{array}{l}\text { Industry will require support from national } \\
\text { government for getting stable - Tourism Industry }\end{array}$ & 2000 & 4.04 \\
\hline Industry will require foreign aid for getting stable - & 2000 & 4.26 \\
\hline Valid N (list-wise) & 2000 & \\
\hline
\end{tabular}

TABLE-7

PERCEIVED NEGATIVE EFFECT OF COVID-19 ON TOURISM INDUSTRY IN PAKISTAN

\begin{tabular}{|l|r|r|}
\hline & \multicolumn{1}{|c|}{ N } & Mean \\
\hline Companies will minimize its operations - Higher & 2000 & 4.01 \\
$\begin{array}{l}\text { Education Industry } \\
\text { There will be a down-sizing in industry - Higher }\end{array}$ & 2000 & 2.95 \\
$\begin{array}{l}\text { Education Industry } \\
\text { Industry will require support from national government } \\
\text { for getting stable - Higher Education Industry }\end{array}$ & 2000 & 2.67 \\
$\begin{array}{l}\text { Industry will require foreign aid for getting stable - } \\
\text { Higher Education Industry }\end{array}$ & 2000 & 1.91 \\
Valid N (list-wise) & 2000 & \\
\hline
\end{tabular}

TABLE-8

PERCEIVED NEGATIVE EFFECT OF COVID-19 ON HIGHER EDUCATION INDUSTRY IN PAKISTAN 


\begin{tabular}{|l|c|c|}
\hline & N & Mean \\
\hline $\begin{array}{l}\text { Companies will minimize its operations - wholesale } \\
\text { and retail Industry }\end{array}$ & 2000 & 2.11 \\
$\begin{array}{l}\text { There will be a down-sizing in industry - wholesale } \\
\text { and retail Industry }\end{array}$ & 2000 & 2.47 \\
$\begin{array}{l}\text { Industry will require support from national } \\
\text { government for getting stable -wholesale and retail }\end{array}$ & 2000 & 1.01 \\
$\begin{array}{l}\text { Industry } \\
\text { Industry will require foreign aid for getting stable - } \\
\text { wholesale and retail Industry } \\
\text { Valid N (list-wise) }\end{array}$ & 2000 & 1.09 \\
\hline
\end{tabular}

TABLE-9

PERCEIVED NEGATIVE EFFECT OF COVID-19 ON WHOLESALE AND RETAIL INDUSTRY IN PAKISTAN

\begin{tabular}{|l|c|c|}
\hline & N & Mean \\
\hline $\begin{array}{l}\text { Companies will minimize its operations - } \\
\text { Transportation Industry } \\
\text { There will be a down-sizing in industry - }\end{array}$ & 2000 & 3.61 \\
$\begin{array}{l}\text { Transportation Industry } \\
\text { Industry will require support from national government } \\
\text { for getting stable - Transportation Industry }\end{array}$ & 2000 & 3.89 \\
$\begin{array}{l}\text { Industry will require foreign aid for getting stable - } \\
\text { Transportation Industry } \\
\text { Valid N (list-wise) }\end{array}$ & 2000 & 3.07 \\
\hline
\end{tabular}

TABLE-10

PERCEIVED NEGATIVE EFFECT OF COVID-19 ON TRANSPORTATION INDUSTRY

\begin{tabular}{|l|c|c|}
\hline & N & Mean \\
\hline $\begin{array}{l}\text { Companies will minimize its operations - Online } \\
\text { Industry }\end{array}$ & 2000 & 2.71 \\
$\begin{array}{l}\text { There will be a down-sizing in industry - Online } \\
\text { Industry }\end{array}$ & 2000 & 2.41 \\
$\begin{array}{l}\text { Industry will require support from national } \\
\text { government for getting stable - Online Industry }\end{array}$ & 2000 & 1.39 \\
$\begin{array}{l}\text { Industry will require foreign aid for getting stable - } \\
\text { Online Industry } \\
\text { Valid N (list-wise) }\end{array}$ & 2000 & 1.12 \\
\hline
\end{tabular}

TABLE-11

PERCEIVED NEGATIVE EFFECT OF COVID-19 ON ONLINE INDUSTRY 
Biannual Research Journal Grassroots Vol.55, No.I: 17-44

\begin{tabular}{|l|c|c|}
\hline & N & Mean \\
\hline $\begin{array}{l}\text { Companies will minimize its operations - Food and } \\
\text { Beverage Industry } \\
\text { There will be a down-sizing in industry - Food and } \\
\text { Beverage Industry }\end{array}$ & 2000 & 2.01 \\
$\begin{array}{l}\text { Industry will require support from national government } \\
\text { for getting stable - Food and Beverage Industry }\end{array}$ & 2000 & 1.41 \\
$\begin{array}{l}\text { Industry will require foreign aid for getting stable - } \\
\text { Food and Beverage Industry } \\
\text { Valid N (list-wise) }\end{array}$ & 2000 & 1.22 \\
\hline
\end{tabular}

TABLE-12

PERCEIVED NEGATIVE EFFECT OF COVID-19 ON FOOD AND BEVERAGE INDUSTRY IN PAKISTAN

\begin{tabular}{|l|c|c|}
\hline & N & Mean \\
\hline Companies will minimize its operations - Publication and & 2000 & 3.22 \\
Print Industry & & \\
$\begin{array}{l}\text { There will be a down-sizing in industry - Publication and } \\
\text { Print Industry }\end{array}$ & 2000 & 2.41 \\
$\begin{array}{l}\text { Industry will require support from national government } \\
\text { for getting stable - Publication and Print Industry }\end{array}$ & 2000 & 2.89 \\
$\begin{array}{l}\text { Industry will require foreign aid for getting stable - } \\
\text { Publication and Print Industry }\end{array}$ & 2000 & 2.49 \\
Valid N (list-wise) & 2000 & \\
\hline
\end{tabular}

\section{TABLE-13}

PERCEIVED NEGATIVE EFFECT OF COVID-19 ON PUBLICATION AND PRINT INDUSTRY

\begin{tabular}{|l|c|c|}
\hline & N & Mean \\
\hline $\begin{array}{l}\text { Companies will minimize its operations -Entertainment } \\
\text { (Drama and Film Industry) }\end{array}$ & 2000 & 2.82 \\
$\begin{array}{l}\text { There will be a down-sizing in industry - Entertainment } \\
\text { (Drama and Film Industry) }\end{array}$ & 2000 & 3.00 \\
$\begin{array}{l}\text { Industry will require support from national government } \\
\text { for getting stable -Entertainment (Drama and Film } \\
\text { Industry) }\end{array}$ & 2000 & 3.59 \\
$\begin{array}{l}\text { Industry will require foreign aid for getting stable - } \\
\text { Entertainment (Drama and Film Industry) } \\
\text { Valid N (list-wise) }\end{array}$ & 2000 & 2.45 \\
\hline
\end{tabular}

TABLE-14

PERCEIVED NEGATIVE EFFECT OF COVID-19

DRAMA AND FILM INDUSTRY 
Biannual Research Journal Grassroots Vol.55, No.I: 17-44

\begin{tabular}{|l|c|c|}
\hline & N & Mean \\
\hline $\begin{array}{l}\text { Companies will minimize its operations - Hotel and } \\
\text { Restaurant Industry } \\
\text { There will be a down-sizing in industry - Hotel and } \\
\text { Restaurant Industry }\end{array}$ & 2000 & 3.83 \\
$\begin{array}{l}\text { Industry will require support from national } \\
\text { government for getting stable -Hotel and Restaurant }\end{array}$ & 2000 & 3.01 \\
$\begin{array}{l}\text { Industry } \\
\text { Industry will require foreign aid for getting stable - } \\
\text { Hotel and Restaurant Industry } \\
\text { Valid N (list-wise) }\end{array}$ & 2000 & 3.52 \\
\hline
\end{tabular}

TABLE-15

PERCEIVED NEGATIVE EFFECT OF COVID-19

HOTEL AND RESTAURANT INDUSTRY

\begin{tabular}{|c|c|c|}
\hline & $\mathbf{N}$ & Mean \\
\hline $\begin{array}{l}\text { Companies will minimize its operations - Telecom } \\
\text { Industry }\end{array}$ & 2000 & 2.10 \\
\hline $\begin{array}{l}\text { There will be a down-sizing in industry - Telecom } \\
\text { Industry }\end{array}$ & 2000 & 2.51 \\
\hline Industry will require support from national & 2000 & \\
\hline government for getting stable - Telecom Industry & & 2.40 \\
\hline Industry will require foreign aid for getting stable - & 2000 & \\
\hline Telecom Industry & & 1.72 \\
\hline Valid N (list-wise) & 2000 & \\
\hline \multicolumn{3}{|c|}{$\begin{array}{c}\text { TABLE-16 } \\
\text { PERCEIVED NEGATIVE EFFECT OF COVID-19 TELECOM INDUSTRY } \\
\end{array}$} \\
\hline & $\mathbf{N}$ & Mean \\
\hline $\begin{array}{l}\text { Companies will minimize its operations - Information } \\
\text { Technology Industry }\end{array}$ & 2000 & 3.00 \\
\hline $\begin{array}{l}\text { There will be a down-sizing in industry - Information } \\
\text { Technology Industry }\end{array}$ & 2000 & 3. 21 \\
\hline $\begin{array}{l}\text { Industry will require support from national government } \\
\text { for getting stable -Information Technology Industry }\end{array}$ & 2000 & 3.40 \\
\hline Industry will require foreign aid for getting stable - & 2000 & 2.41 \\
\hline Information Technology Industry & & \\
\hline Valid N (list-wise) & 2000 & \\
\hline
\end{tabular}

TABLE-17

PERCEIVED NEGATIVE EFFECT OF COVID-19

INFORMATION TECHNOLOGY INDUSTRY 


\begin{tabular}{|l|c|c|}
\hline & N & Mean \\
\hline $\begin{array}{l}\text { Companies will minimize its operations - } \\
\text { Pharmaceutical Industry } \\
\text { There will be a down-sizing in industry - }\end{array}$ & 2000 & 2.02 \\
$\begin{array}{l}\text { Pharmaceutical Industry } \\
\text { Industry will require support from national } \\
\text { government for getting stable -Pharmaceutical }\end{array}$ & 2000 & 1.21 \\
$\begin{array}{l}\text { Industry } \\
\text { Industry will require foreign aid for getting stable - } \\
\text { Pharmaceutical Industry } \\
\text { Valid N (list-wise) }\end{array}$ & 2000 & 1.22 \\
\hline
\end{tabular}

TABLE-18

PERCEIVED NEGATIVE EFFECT OF COVID-19 PHARMACEUTICAL INDUSTRY

\begin{tabular}{|c|c|c|}
\hline & $\mathbf{N}$ & Mean \\
\hline $\begin{array}{l}\text { Companies will minimize its operations - Banking } \\
\text { Industry }\end{array}$ & 2000 & 3.04 \\
\hline $\begin{array}{l}\text { There will be a down-sizing in industry - Banking } \\
\text { Industry }\end{array}$ & 2000 & 2.97 \\
\hline $\begin{array}{l}\text { Industry will require support from national } \\
\text { government for getting stable -Banking Industry }\end{array}$ & 2000 & 3.18 \\
\hline $\begin{array}{l}\text { Industry will require foreign aid for getting stable - } \\
\text { Banking Industry }\end{array}$ & 2000 & 3.10 \\
\hline
\end{tabular}

TABLE-19

PERCEIVED NEGATIVE EFFECT OF COVID-19 BANKING INDUSTRY

\begin{tabular}{|l|c|c|}
\hline & N & Mean \\
\hline Companies will minimize its operations - Fashion & 2000 & 3.67 \\
Industry & 2000 & 3.82 \\
There will be a down-sizing in industry - Fashion & & \\
Industry & 2000 & 3.48 \\
Industry will require support from national & & \\
government for getting stable -Fashion Industry & 2000 & 3. \\
Industry will require foreign aid for getting stable - & & 70 \\
Fashion Industry & 2000 & \\
Valid N (list-wise) &
\end{tabular}

TABLE-20

PERCEIVED NEGATIVE EFFECT OF COVID-19 FASHION INDUSTRY 


\begin{tabular}{|l|c|c|}
\hline & N & Mean \\
\hline $\begin{array}{l}\text { Companies will minimize its operations - News and } \\
\text { Information Industry }\end{array}$ & 2000 & 1.27 \\
$\begin{array}{l}\text { There will be a down-sizing in industry - News and } \\
\text { Information Industry }\end{array}$ & 2000 & 1.52 \\
$\begin{array}{l}\text { Industry will require support from national government } \\
\text { for getting stable -News and Information Industry } \\
\text { Industry will require foreign aid for getting stable - } \\
\begin{array}{l}\text { News and Information Industry } \\
\text { Valid N (list-wise) }\end{array}\end{array}$ & 2000 & 0.98 \\
\hline
\end{tabular}

\section{TABLE-21}

PERCEIVED NEGATIVE EFFECT OF COVID-19 NEWS AND INFORMATION INDUSTRY

\begin{tabular}{|l|c|c|}
\hline & N & Mean \\
\hline Companies will minimize its operations - Agriculture & 2000 & 3.10 \\
$\begin{array}{l}\text { Industry (Crop Sector) } \\
\text { There will be a down-sizing in industry - Agriculture }\end{array}$ & 2000 & 3.62 \\
$\begin{array}{l}\text { Industry (Crop Sector) } \\
\text { Industry will require support from national government } \\
\text { for getting stable -Agriculture Industry (Crop Sector) }\end{array}$ & 2000 & 3.49 \\
$\begin{array}{l}\text { Industry } \\
\begin{array}{l}\text { Industry will require foreign aid for getting stable - } \\
\text { Agriculture Industry (Crop Sector) } \\
\text { Valid N (list-wise) }\end{array}\end{array}$ & 2000 & 3.60 \\
\hline
\end{tabular}

TABLE-22

PERCEIVED NEGATIVE EFFECT OF COVID-19 AGRICULTURE INDUSTRY (CROP SECTOR)

\begin{tabular}{|l|c|c|}
\hline & N & Mean \\
\hline Companies will minimize its operations - Agriculture & 2000 & 3.00 \\
Industry (Livestock Sector) & & \\
There will be a down-sizing in industry - Agriculture & 2000 & 3.00 \\
Industry (Livestock Sector) & 2000 & 2.71 \\
$\begin{array}{l}\text { Industry will require support from national government } \\
\text { for getting stable -Agriculture Industry (Livestock }\end{array}$ & & \\
Sector) & 2000 & 2. \\
Industry will require foreign aid for getting stable - & & 09 \\
Agriculture Industry (Livestock Sector) & 2000 & \\
Valid N (list-wise) & & \\
\hline
\end{tabular}

TABLE-23

PERCEIVED NEGATIVE EFFECT OF COVID-19 AGRICULTURE INDUSTRY (LIVESTOCK SECTOR) 
Biannual Research Journal Grassroots Vol.55, No.I: 17-44

\begin{tabular}{|l|c|c|}
\hline & N & Mean \\
\hline Companies will minimize its operations - Textile & 2000 & 3.91 \\
Industry & & \\
There will be a down-sizing in industry - Textile & 2000 & 3.87 \\
Industry & 2000 & 3.61 \\
Industry will require support from national \\
government for getting stable -Textile Industry \\
$\begin{array}{l}\text { Industry will require foreign aid for getting stable - } \\
\text { Textile Industry }\end{array}$ & 2000 & 3.09 \\
Valid N (list-wise) & 2000 & \\
\hline
\end{tabular}

TABLE-24

PERCEIVED NEGATIVE EFFECT OF COVID-19 TEXTILE INDUSTRY

\begin{tabular}{|l|c|c|}
\hline & N & Mean \\
\hline Companies will minimize its operations - & 2000 & 3.00 \\
Construction Industry & 2000 & \\
There will be a down-sizing in industry - & & 2.95 \\
Construction Industry & 2000 & 2.63 \\
Industry will require support from national & & \\
government for getting stable -Construction & & \\
Industry & 2000 & 2.09 \\
Industry will require foreign aid for getting stable - & & \\
Construction Industry & 2000 & \\
Valid N (list-wise) & &
\end{tabular}

TABLE-25

PERCEIVED NEGATIVE EFFECT OF COVID-19 CONSTRUCTION INDUSTRY

\begin{tabular}{|l|c|c|}
\hline & N & Mean \\
\hline Companies will minimize its operations -School and & 2000 & 3.07 \\
$\begin{array}{l}\text { Education Industry } \\
\text { There will be a down-sizing in industry - School and } \\
\text { Education Industry }\end{array}$ & 2000 & 4.27 \\
$\begin{array}{l}\text { Industry will require support from national government } \\
\text { for getting stable -School and Education Industry } \\
\text { Industry will require foreign aid for getting stable - } \\
\begin{array}{l}\text { School and Education Industry } \\
\text { Valid N (list-wise) }\end{array}\end{array}$ & 2000 & 3.54 \\
\hline
\end{tabular}

TABLE-26

PERCEIVED NEGATIVE EFFECT OF COVID-19

SCHOOL AND EDUCATION INDUSTRY 


\begin{tabular}{|l|c|c|}
\hline & N & Mean \\
\hline $\begin{array}{l}\text { Companies will minimize its operations - } \\
\text { Automobile and Mechanical Industry } \\
\text { There will be a down-sizing in industry - }\end{array}$ & 2000 & 3.40 \\
$\begin{array}{l}\text { Automobile and Mechanical Industry } \\
\text { Industry will require support from national } \\
\text { government for getting stable -Automobile and } \\
\text { Mechanical Industry }\end{array}$ & 2000 & 3.87 \\
$\begin{array}{l}\text { Industry will require foreign aid for getting stable - } \\
\text { Automobile and Mechanical Industry } \\
\text { Valid N (list-wise) }\end{array}$ & 2000 & 3.71 \\
\hline
\end{tabular}

TABLE-27

PERCEIVED NEGATIVE EFFECT OF COVID-19 ON AUTOMOBILE AND MECHANICAL INDUSTRY

\begin{tabular}{|l|c|c|}
\hline & N & Mean \\
\hline Companies will minimize its operations -Distribution & 2000 & 2.22 \\
and Logistic Industry & & \\
There will be a down-sizing in industry - Distribution and & 2000 & \\
Logistic Industry & & 2.06 \\
Industry will require support from national government & 2000 & 1.44 \\
for getting stable -Distribution and Logistic Industry & & \\
Industry will require foreign aid for getting stable- & 2000 & 1.02 \\
Distribution and Logistic Industry & & \\
Valid N (list-wise) & 2000 & \\
\hline
\end{tabular}

TABLE-28

PERCEIVED NEGATIVE EFFECT OF COVID-19

ON DISTRIBUTION AND LOGISTIC INDUSTRY

\begin{tabular}{|l|c|c|}
\hline & N & Mean \\
\hline Companies will minimize its operations -Electrical and & 2000 & 3.32 \\
Electronics Industry & & \\
There will be a down-sizing in industry - Electrical and & 2000 & 3.51 \\
$\begin{array}{l}\text { Electronics Industry } \\
\text { Industry will require support from national government } \\
\text { for getting stable -Electrical and Electronics Industry } \\
\text { Industry will require foreign aid for getting stable - } \\
\begin{array}{l}\text { Electrical and Electronics Industry } \\
\text { Valid N (list-wise) }\end{array}\end{array}$ & 2000 & 3.42 \\
\end{tabular}

TABLE-29

PERCEIVED NEGATIVE EFFECT OF COVID-19 ON ELECTRICAL AND ELECTRONICS INDUSTRY 
Table 6-29 are indicating perceived harmful effects of COVID19 on different industries among them there are few industries like pharmaceutical, food and beverage, online, news \& information, wholesale and retail and distribution industries with least effect of COVID-19. Although most of the industries like airline, transportation, travelling \& tourism, fashion, textile, schooling \& education, agriculture, hotel \& restaurant, automobile \& mechanical, print \& publication information technology, higher education \& electrical and electronics etc. with more critical effect of COVID-19. Moreover, it has also been indicated that banking and construction industries are those which have neutral effect of COVID-19 as far as public opinion is concerned. Analysis has been made through referring four questions regarding defensive strategies and survival requirements for range of industries mentioned in the analysis. Industries' like airline, textile, tourism \&transportation are found to be lying at top with respect to defensive strategies i.e. minimize operations and downsizing with perceived values are $3.96 \& 3.97$ for airline3.95 \& 3.98 for tourism, 3.91 and 3.87 for textile and $3.61 \&$ 3.89 in transportation.

After highlighting industries which might experience extraordinary negative impacts of COVID-19, results also indicated two industries i.e. automobile \& mechanical and electronics which will experience above average negative impacts of the virus. This is evident through the mean scores of 340 \& 3.87 for automobile \& mechanical industry and $3.32 \& 3.51$ for electronics \& electrical industry obtained in against of defensive strategies i.e. minimize operations and downsizing. Then there are industries like schooling \& education and agriculture (crop sector) which will not decrease their operations to the deal as airline, tourism etc. although in order to revive there will be a massive downsizing. This has been indicated by mean scores $3.07 \& 4.27$ for schooling \& education and $3.10 \& 3.60$ for agriculture (crop sector). Contrary to this is the scenario of higher education industry where there will be a massive decrease in the operation i.e. score of 4.01 although there will not be massive downsizing in comparison to the industries mentioned earlier as indicated by score of 2.95 .

On the other side there are industries which are least affected by the COVID-19 as indicated by the mean scores based on the public 
opinion, including wholesale and retail, pharmaceutical, online, news $\&$ information and logistic and distributions etc. This is evident through the lower scores obtained as respondents believe these industries might not decrease their operations due to COVID-19. News $\&$ Information Pharmaceutical and Food and Beverage industries are perceived to experience least negative effects the virus as the mean score for defensive $1.27 \& 1.54,2.02 \& 1.21$ and $2.01 \& 1.41$ hence there are least chance for decrease in operations and layoffs. Similar found true for wholesale \& retail and telecom industries where the scores are $2.11 \& 2.47$ and $2.10 \& 2.51$. Other industries which experience mild effects of COVID-19 includes online industry, distribution and logistics industry, publication and print industry, drama \& film industry, and livestock sector of agriculture industry. This is evident through the mean scores of $2.71 \& 2.41,3.00 \& 3.00$, and $2.88 \& 3.00$ in against of the questions which are used to measure defensive strategies of these companies.

Last but not the least there are some companies like banking industry and construction industry etc. which might experience medium effects of COVID-19. The mean scores according to the perception of residents are not under 2.50 but not even above 3 . Hence these industries cannot be grouped with those which will experience massive effect of COVID-19 like airline and fashion etc. and neither can be grouped with those which will experience least effects as news and information. Therefore, these industries are included in to the third group with industries' having average effects of COVID-19. Moving towards the survival requirements the industry which require most support from local as well as International welfare bodies and other governments is tourism industry as result indicated mean score of 4.04 and 4.26.

Then it is the number of automobile and mechanical industry which is also getting highly dependent on local government as well as funding from international sources as the mean scores are $3.71 \& 3.89$. Similar valid for the fashion, banking, textile industries\& electronics $\&$ electrical equipment and transportation industries which needs high support from local government and also from international bodies as the mean scores are $3.48 \& 3.70,3.18 \& 3.10 ; 3.61 \& 3.09 ; 3.42 \&$ 3.19 and $3.07 \& 2.42$. 
Thus, the transportation industry is the one which require more support from local government as compared to the international bodies. On the other hand, airline industry, hotel \& restaurant, drama $\&$ film; agriculture (crop sector); information technology \&school and education are industries which requires massive support from local as well as international bodies though proportion of support from local government is understandably higher than the support from international bodies. This has been highlighted by the scores $4.00 \&$ $3.27 ; 3.90 \& 3.52 ; 3.59 \& 2.45 ; 3.49 \& 3.60 ; 3.40 \& 2.41$ and $3.54 \&$ 2.29 hence legitimate to declare airline industry as different from the other industries like fashion, banking, textile industries \& electronics \& electrical equipment and transportation. Hence these industries will require more support from local government than the support from international bodies. Other than these high effects of COVID-19 there are some industries which require above average support from local government as well as international bodies e.g. publication \& print, agriculture (livestock sector) and construction industries with the mean scores of $2.96 \& 2.89 ; 2.71 \& 2.09$ and $2.63 \& 2.09$. respectively. Moving towards the industries which require least support from local government as well as international bodies the industry of news and information requires the least as mean scores are $0.98 \& 0.70$, respectively. Then comes the industry of wholesale and retail, food and beverage, pharmaceutical, online, distribution and logistics; telecom industries and higher education respectively with mean scores of $1.01 \& 1.09,1.06 \& 1.22 ; 1.39 \& 1.12 ; 1.40 \& 1.22 ; 1.44 \& 1.02$; $2.40 \& 1.72$ and $2.67 \& 1.91$.

\section{DISCUSSION}

Results indicated that most of the business got negatively influenced by COVID-19 although there is some form of business which shows positive outcomes due to the spread of virus. Similar has been indicated by Turner and Akinremi (2020) that the effect of COVID-19 was not homogeneous all over China. It creates most drastic impact of small and medium sized enterprises and effect supply as well as demand functions through decreasing ability to buy from buyers as well as ability to produce from producers.

Hence coherent with the indications of Eichenbaum et.al., (2020) and also with Correia and Luck (2020) as study indicated that there is a massive decrease in level of employment in most of the industries as 
well as in consumption of durable goods and banking services. Findings of the study are also found bit similar to Nipah (Malaysia) where 111 banks, shops and schools got closed and 36,000 people lost their jobs (Smith et.al., 2019).

Hence the effect caused by COVID-19 on banking, but the findings of Smith et al (2019) indicated that breakout of SARS also affected business of retail sector which is not in the case of COVID19. Though results are highly coherent with MERS which resulted in $41 \%$ decrease in South Korea \&US \$ 5 billion/ year decrease in SaudiArabia.

\section{AREA FOR FUTURE RESEARCH}

This is one of the initial studies on the impacts of COVID-19 on different form of industries and hence based upon public opinion in order to guide policy makers in policy making and governing lockdowns, Although the study is not based on data associated with real effects therefore further research work might be carried through conducting specific research on different industries' through qualitative design and expert survey before availability of quantitative data and with quantitative technique after availability of data.

\section{REFERENCES}

Adu-Gyamfi, J. (2014). Young people's participation in the formulation and implementation of Ghana's youth policy. Youth Voice Journal, https://wp.me/p3pv0f-7F

Ahmed, R., \& Mahmood, K. (2012). Spatio-temporal Changes in Economic Development: A Case Study of Sindh Province. Karachi University Journal of Science, 40, 25-30.

Asian Development Bank. (2020, April 3). Developing Asia Growth to Fall in 2020 on COVID-19 Impact. https://www.adb.org/news/developing-asiagrowth-fall-2020-covid-19-impact

Bijian, L., (2020, March 28). Impact of COVID-19 on economy of Pakistan. The Business Recorder, https://www.brecorder.com/2020/03/28/584351/ impact-of-covid-19-on-economy-of-pakistan/

Bloom, D. E., \& Mahal, A. S. (1995). Does the AIDS epidemic really threaten economic growth? (No. w5148). National Bureau of Economic Research.

Bloom, D. E., Cadarette, D., \& Sevilla, J. (2018). Epidemics \& Economics. Finance \& Development, 55(2), 46-49.

Bloom, D., \& Canning, D. (2006). Epidemics and Economics. Program on the global demography of aging. Working Paper Series.

Burstein, P. (2003). The impact of public opinion on public policy: A review and an agenda. Political research quarterly, 56(1), 29-40. 
Correia, S. \& Luck, S., (2020, April 2). How can we save lives and the economy? Lessons from the Spanish Flu pandemic. World Economic Forum, https://www.weforum.org/agenda/2020/04/pandemic-economy-lessons1918-flul

Davies, S. E. (2013). National security and pandemics. UN Chronicle, 50(2), 2024

Deling, H. \& Diren, L. (2015). The Analysis of Public Opinion About ChinaPakistan Economic Corridor. Proceedings of International Conference on CPEC, GC University, Lahore

Deling, H., Diren, L., \& Tiantian, H. (2016). Analysis of Public Opinion About China-Pakistan Economic Corridor. Journal of Applied Sciences, 16(6), 286-29

Dimitri, N. (2015). The economics of epidemic diseases. PloS one, 10(9), doi: 10.1371/journal.pone.0137964.

Dulock, H. L. (1993). Research design: Descriptive research. Journal of Pediatric Oncology Nursing, 10(4), 154-157

Eichenbaum, M. S., Rebelo, S., \& Trabandt, M. (2020). The macroeconomics of epidemics (No. w26882). National Bureau of Economic Research.

Faisal, M., (2020, March 24). Pakistan's evolving response to COVID-19, STIMSON, https://www.stimson.org/2020/pakistans-evolving-responseto-covid-19/

Gill, J., \& Johnson, P. Clark. M. (2010) Research Methods for Managers, SAGE Publications.

Guo, Y. R., Cao, Q. D., Hong, Z. S., Tan, Y. Y., Chen, S. D., Jin, H. J. \& Yan, Y. (2020). The origin, transmission, and clinical therapies on coronavirus disease 2019 (COVID-19) outbreak-an update on the status. Military Medical Research, 7(1), 1-10 https://www.imf.org/external/pubs/ft/fandd /2018/06/economic-risks-and-impacts-of-epidemics/bloom.htm

Israel, G. D. (1992). Determining sample size. University of Florida

Johns, R. (2005). One size does not fit all: Selecting response scales for attitude items. Journal of Elections, Public Opinion \& Parties, 15(2), 237-264

Johns, R. (2010). Survey question bank: Methods Fact Sheet 1, Likert items and scales. University of Strathclyde

Koh, E. T., \& Owen, W. L. (2000). Descriptive research and qualitative research. In Introduction to Nutrition and Health research (pp. 219-248). Springer, Boston, MA

Mc Manus, P., Mulhall, S., Ragab, M., \& Arisha, A. (2017, June). An Investigation in the Methodological Approaches used in Doctoral Business Research in Ireland. In ECRM 2017 16th European Conference on Research Methods in Business and Management (p. 233). Academic Conferences and publishing limited

McCarthy, N. (2020, February 12). How SARS Impacted Global Economies. Statista, https://www.statista.com/chart/20800/impact-of-sars-on-real-gdp/

McKibbin, W. J., \& Fernando, R. (2020). The global macroeconomic impacts of COVID-19: Seven scenarios, CAMA Working Paper No. 19/2020,v http://dx.doi.org/10.2139/ssrn.3547729 
Qiu, W., Rutherford, S., Mao, A., \& Chu, C. (2017). The Pandemic and its Impacts. Health, Culture and Society, 9, 1-11

Sale, J. E., Lohfeld, L. H., \& Brazil, K. (2002). Revisiting the quantitativequalitative debate: Implications for mixed-methods research. Quality and quantity, 36(1), 43-53

Salik, K. M., Ishfaq, S., Saeed, F., Noel, E., \& Syed, Q. U. A. (2015). Pakistan country situation assessment, Pathways to Resilience in Semi-arid Economies (PRISE) project

Saunders, M., Lewis, P., \& Thornhill, A. (2009). Research onion. Research methods for business students, 136-162

Sekaran, U., \& Bougie, R. (2016). Research methods for business: A skill building approach. John Wiley \& Sons

Siu, A., \& Wong, Y. R. (2004). Economic impact of SARS: the case of Hong Kong. Asian Economic Papers, 3(1), 62-83

Smith, K. M., Machalaba, C. C., Seifman, R., Feferholtz, Y., \& Karesh, W. B. (2019). Infectious disease and economics: The case for considering multisectoral impacts. One Health, 7, 100080

Suleri, A. Q., (2020, March 16). Dealing with Covid-19 in Pakistan. The News International, https://www.thenews.com.pk/print/629602-dealing-withcovid-19-in-pakistan

Sultan, M. F., Ahmed, I. \& Zafar, M. R. (2017). Measuring the Impact of China Pakistan Economic Corridor on the Socio-Economic Aspects of Pakistan: A Quantitative Research Highlighting the Public Opinion. Journal of Economics and Sustainable Development, 8(23), 46-56

Sultan, M. F., Omar, M., \& Imtiaz, R. (2019). Analyzing Prevalent Internal Challenges to China Pakistan Economic Corridor (CPEC) through Public Opinion, Journal of Economics and Sustainable Development, 10(7), 1-9

Taherdoost, H. (2017). Determining sample size; how to calculate survey sample size. International Journal of Economics and Management Systems, 2, 237-239

Tashakkori, A., \& Teddlie, C. (2008). Quality of inferences in mixed methods research: Calling for an integrative framework. Advances in mixed methods research, 101-119.

Turner, J and Akinremi, T. (2020). The business effects of pandemics - a rapid literature review. ERC Insight Paper, Enterprise Research Center, www.enterpriseresearch.sc.uk

Verikios, G., Sullivan, M., Stojanovski, P., Giesecke, J., \& Woo, G. (2016). Assessing regional risks from pandemic influenza: a scenario analysis. The World Economy, 39(8), 1225-1255

Wang, C., Pan, R., Wan, X., Tan, Y., Xu, L., Ho, C. S., \& Ho, R. C. (2020). Immediate psychological responses and associated factors during the initial stage of the 2019 coronavirus disease (COVID-19) epidemic among the general population in china. International Journal of Environmental Research and Public Health, 17(5), 1729, https://doi.org/10.3390/ ijerph17051729 